\title{
Intercultural and Community Schools. Learning to Live Together
}

\author{
Andrés Escarbajal-Frutos ${ }^{1, *}$, Tomás Izquierdo-Rus ${ }^{2}$, Inmaculada Aznar-Díaz ${ }^{3}$ (i) \\ and María Pilar Cáceres-Reche ${ }^{3}$ (D) \\ 1 Department of Didactics and School Organization, University of Murcia, 30100 Murcia, Spain \\ 2 Department of Research Methods and Diagnostic in Education, University of Murcia, 30100 Murcia, Spain \\ 3 Department of Didactics and School Organization, University of Granada, 18071 Granada, Spain \\ * Correspondence: andreses@um.es
}

Received: 30 April 2019; Accepted: 18 June 2019; Published: 9 July 2019

\begin{abstract}
We must remember the need to create communicative relationships among groups from different cultures, as well as to reinforce the configuration and organisation of the Spanish school system. The objective of this article is to highlight the urgent need to recognise cultural, religious and linguistic diversity as values. Furthermore, Spain has rejected the French assimilationist model, both in legal and practical spheres, and the only way to integrate this model is by implementing intercultural models. Following the Convention on the Promotion of the Diversity of Cultural Expression of the European Union, providing respect and recognition of plurality from intercultural inclusive positions is primordial in the learning context. We cannot talk about building an intercultural society without considering democratic practice and citizen participation; to this regard, dialogue and collaboration between the school community and educational centres are imperative. It is necessary to adopt an inclusive intercultural policy, to open education centres outside of traditional school hours, to reach agreements with cultural institutions, etc. Only in this way will an intercultural society become a reality.
\end{abstract}

Keywords: education; community; school; intercultural; dialogue

\section{Introduction}

It is notable that schools, which are basic educational institutions, are deeply affected by what [1] named "the outbreak of globalisation and multiculturalism" (p. 90), understanding "globalisation" as a real material, technological, economic and social revolution promoting contact between countries; and "multiculturalism" as the coexistence between different cultural groups within a geopolitical framework with the same state and regional regulations, though without reaching a reciprocal relationship on equal levels [2].

Indeed, whether we like it or not, globalisation is not only economic (a matter that, naturally, has an impact on schools), but also cultural, which places - or should place - multiculturalism at the centre of educational policies, especially those designed for schools. If one of the traditional pillars of schools has always been to achieve pupils' socialisation, and to make them participate in a culture built with the passing of the years in a specific space, then we should ask whether this aim remains valid in today's multicultural society and to what extent [3], particularly considering that there are two risks in multicultural societies: firstly, the rigidity and isolation that result from the fear of others due to the fear of losing one's own identity; secondly - and in contrast - if globalisation is seen in an acritical way, cultural uniformity appears as an overcrowding trend that suppresses diversity. Therefore, schools have an unavoidable job to do in this area to critically counter these two opposite possibilities: localism versus global homogenisation. 
As per the above, since the economy and entrepreneurial capacity seemed to be the options around which educational practice should revolve, the pillar of "Learn to live together" reappeared, becoming a basic priority $[4,5]$. In "Learn to live together", intercultural dialogue refers to the constructive connection of differences as plural and open constructions of new cultures from what each cultural group brings to the table. Difference is not seen as a risk, but as a value and an integrating (in the best sense possible) complex synergy. If we are convinced that differences are positive insofar as they enrich culture, we will also agree on the fact that the basic educational institution - school must "prepare pupils to live and coexist in changing and heterogeneous environments" [6] (p. 145). Thanks to schools" power of transformation and their restorative approach [7] through their practice of mediation among peers and their strategic group teaching methods, these institutions facilitate interculturality by improving the relational atmosphere, cohabitation, respect, and dialogue.

We must remember to this regard that the need to create communicative relationships among groups from different cultures arose in some European countries in the 1960s, when there was a significant arrival of immigrants (although emigration had started shortly after the Second World War ended). At that time, schools implemented programmes with multicultural contents to focus on cultural aspects related to food, lifestyles, folklore, clothing, etc. to provide pupils with the chance to learn more about cultural diversity. Nevertheless, some years later strong opposition arose against this way of understanding education through multicultural contexts, since it was considered superficial, and critics warned about creating stereotypes and prejudices towards immigrant cultures. Moreover, the most criticised element was the fact that those practices left some important aspects out of the school debate, like racism, social exclusion and power management [8].

It is also important to highlight what [9] showed: that the design and organisation of the Spanish school system are not highly conducive to developing intercultural education. Therefore, this author $[10,11]$ believes that, through the experience in Spain over recent years, together with the knowledge resulting from numerous pieces of research on this matter, some elements that could hinder interculturality should be considered when intending to develop it at schools. These include the origin of immigrant families who usually have impoverished economic conditions with little or no schooling tradition for their children; pupils coming from non-Spanish speaking countries not knowing the host language (which creates an obstacle, not only at an educational level, but also at the emotional and social inclusion level); the massive increase of immigrant pupils in state schools, which frequently means a real "ghettoissation" of such schools; religious conflicts which, even if not very common and we should not generalise, are a contributing factor towards the radicalisation of positions in the future; the lack of involvement of immigrant families in schools; the lack of teachers who are specially trained in interculturality; and above all, the meagre or absent political will to foster interculturality.

In any case, it is important to recognise that, despite the huge number of journals and books on interculturality, we still might need to apply the Gramscian concept of praxis, to integrate theory and practice in the same action, or as [12] states, "to show that there is a theory behind intercultural practice ... , moving from a period of rhetoric on interculturality to one of action" (p. 5). What is clear is that words currently prevail over practice in the intercultural context and that, as [13] argued, schools (and other educational institutions) are becoming incubators of competitive individualism and individual mobility.

According to [14], with the economic crisis arose another crisis, among other issues: the public sphere could not control private interests, which acted as if no rules or regulations existed. In such a context, segregating attitudes and practices abruptly appeared. But schools should not follow such dynamics: they should not ignore individual tendencies, and they are responsible for acting against those tendencies in classes and in direct connection with the surrounding community.

\section{Intercultural Schools}

As a guarantee of freedom, sections 1.1 and 16.1 of the Spanish Constitution recognise the principle of pluralism - surely referring to political pluralism. However, this concept was subsequently legally 
construed in the broader sense, with multiculturalism being an appropriate framework for personal and individual development. Along the same lines, article 82 of the Charter of Fundamental Rights of the European Union recognises cultural, religious and linguistic diversity as values. Furthermore, Spain has rejected the French assimilationist model, both in legal and practical spheres, and the only way to integrate in Spain is through intercultural models. Indeed, the importance of the educational treatment of multiculturalism [15] derives from this legal framework. Hence, from a legal point of view, cultural diversity is a right, and its development corresponds to public policies in a Welfare State.

The European Union itself [16] following the Convention on the Promotion of the Diversity of Cultural Expression, defined interculturality as the equal presence and interaction of diverse cultures, as a real possibility to generate hybrid and shared cultures, as an intercultural dialogue from mutual respect. The Spanish legal system also recognises it as one of the aims of the education system (section 2.1.g. of the Organic Act 2/2006 of 3rd May, which deals with educating in respect and recognition of plurality from intercultural and inclusive positions) [17].

For all of the above, [15] pushes for what he calls democratic constitutional miscegenation, which comprises both legal and regulatory levels, and the materialisation in specific social policies. It is called a cultural melting pot within the Spanish constitutional framework, and a permanent lever for restoring a democratic system.

Although the aim of schools in most Nation States was educating citizens for them to internationalise national values, and schools assumed that it was necessary to assimilate the dominant culture to develop a sense of national belonging, this aim is obsolete today in a world where nationalism and globalisation coexist in global tension.

Nor can schools assume their traditional role as an agent of socialisation. In the past, regulatory reference frameworks, visions of the world and of one's own identity were provided by schools, families and the Church, assuring social cohesion. However, now individuals are isolated in the face of an increasingly anonymous community. Social insertion seems more an individual rather than a collective question. It falls to education, then, to create the sense of belonging, to develop the ability to articulate complex identities with belonging to multiple spheres. In this sense, the role of the school remains key to developing the plural feeling of belonging, by activating mechanisms that foster the construction of democratic educational experiences at a community level. Therefore, [18] opts for schooling that is:

Public, inclusive, democratic, secular, respectful of the diversity and singularity of each person, that takes into account difference and promotes an equality that is intercultural and mixed, coeducational, innovative, liberating, solidary and committed to the issues, hopes and joys of humanity, that feed the dreams of human fulfilment in every single person. (p. 77)

Nevertheless, it is important to bear in mind [19] words, which say that even in times of change, the inertia of the past and continuity remain a constant within educational systems. This means that interculturality in schools will not be produced by mere contact between pupils from different cultures, but that it is also necessary to be clear about the principles that inspire them, to design a coherent project with those principles, and to develop that project jointly and responsibly at a community level. As [20] explains, how the school space is organised will be paramount; that educational ecosystem will rely on the fact that open interactions with others and the inclusion of everyone happen, or the opposite. Therefore, the starting point for an intercultural project in schools is knowing the action context, including the educational centre with all its features.

It is also true that the teaching process at school, even if critical, has a limited scope due to the power of other social instances. However, that does not necessarily mean that we have to put aside critical attitudes in favour of a social pragmatism that only leads to the exclusion [21] of those who are "at the bottom" of the social ladder; educational institutions must always be spaces for hope [22] since the same logic prevails in school organisations as in markets - a neoliberal capitalist logic. In contrast, this author states that even though schools reproduce the dominant ideology, it is also true that it is 
possible to coordinate resistance spaces from schools. However, doing so would require thinking about how to "develop a pedagogy that recognises spaces, tensions and possibilities of struggle within the ordinary working of schools" [23] (p. 174). Therefore, intercultural schools should consider Furman's words [24] on the three visions of justice in such educational institutions:

a) Distributive justice: To build a syllabus that is common, intercultural, comprised of relevant contents and essential lessons accessible to everyone.

b) Cultural justice: To recognise pupils' social differences, to value these differences positively and to deal with them according to each pupil's needs.

c) Associative justice: To establish solid networks of social capital among schools, families and the community.

The world is heterogeneous and diverse, and education and educational syllabuses must prepare pupils for this context and identify the possible barriers hindering everyone's learning and participation with the maximum democratic guarantees [25]. This implies the selection, preparation and development of a syllabus that silences no-one [26]; a syllabus that contributes to mutual growth, that avoids segregating answers focused on the deficit, and that assures equality, quality and social cohesion [20].

It is important to bear in mind that one of the objectives of the intercultural syllabus is that pupils can progressively acquire the knowledge, attitudes and skills of responsible citizens in a culturally diverse world [27]. But most current European syllabuses have not been designed from an intercultural perspective, nor have they overcome their Eurocentric view [28]. This fact currently makes it obligatory to develop universal and intercultural syllabuses that consider other cultures, which would benefit everyone and would improve and broaden knowledge, would train better citizens, and would better prepare pupils for a globalised world [29]. Considering this, an educational centre without an Intercultural Educational Programme will be a fertile breeding ground for segregating processes and exclusion dynamics [20]. Nevertheless, in reality it is said that School Education Programmes (PECs in Spanish) are usually mere bureaucratic documents and declarations of intent, rather than materials for thinking orientated to classroom practice. This should not be the case, given that developing good practices will rely on work within the school and its specific context, and on the programme designed by everyone [26].

Despite criticism, schools remain an extraordinary tool to foster interculturality, the culture of peace, and to ensure equal opportunities from the perspective of an open, democratic and plural society [30]. As [31] state, today schools are still an indispensable social agent to educate on values of participation and social justice and to insist on the idea that the intercultural perspective is, above all, a way to interact and discuss that does not arise spontaneously, but must be laboriously built, educated and conquered against stereotypes and prejudices. Hence, intercultural education leads to a radical renewal of schools.

To summarise, we can talk, write and think about interculturality, but we must always look to schools to lay the foundations. Teachers and families must be the ones to act as engineers, building intercultural bridges in multicultural spaces. Intercultural education should be understood as a necessity rather than a possibility [32], backed up by an ideological approach that supports and inspires it, based on the Universal Declaration of Human Rights. The evidence provided by research shows that the intercultural perspective is not permeating educational processes, especially including but not limited to the educational context [33].

\section{Schools with Community Vocation}

In October 2013 a meeting of the SIRIUS network (Policy Network on Migrant Education) took place in Madrid. This name refers to the organisation that analyses the implementation of European Union policies on European immigration, in order to assess the basic compulsory education of foreign pupils, and to propose improved alternatives. The analysis carried out recognises, from a legislative perspective, the right of foreign citizens' children to receive education in equal conditions as local 
pupils. What generally happens is that, as with other legislation and principles, that right is cut off or it is just breached, which has two main consequences, in Spain at least [34] (pp. 15-16):

a) Dualisation and ghettoisation of the system: There are large differences between the schooling of foreign citizens' children in state and private or semi-private schools; the latter only accepts the minimum number of pupils established by legislation. Therefore, there are $82.3 \%$ of foreign citizens' children registered in state schools, $13.7 \%$ in semi-private schools, and a mere $4 \%$ in private centres, according to the Spanish Ministry of Education [35].

b) Disarticulation: There are still difficulties for the access and progression of pupils from foreign origins; few go up the levels and they show high rates of school dropout at A-level (Bachillerato in Spain), according to [36].

Then, the aforementioned meeting of the SIRIUS network concluded that there are a wide range of difficulties for implementing intercultural policies due to a lack of resources, problems for network connections among centres, and insufficient means to follow up registrations, reception and access from some phases to others by foreign citizen's children, and the permanence of these pupils in the education system. Moreover, the ability of the current education system to provide a quality education for everyone, without discrimination, is called into question. There are insufficient means to foster educational inclusion, individualised attention and family-school cooperation [34].

Among the alternatives offered by the SIRIUS network, those that refer to the school-environment relationship are notable. It is recommended to promote community approaches, integrate all social players in a network to "do together", and generate new forms of schooling that must be contextualised for effective inclusion [34]. As also stated by [37] the innovation in terms of foreign pupils' schooling has more to do with the school-community relationship than with general policies applied by the Administration. The Delors Report [38] expressed how important community participation and commitment with schools are:

When communities become more responsible for their own development, they learn how to value education's role, understood both as a means to reach specific social goals and as an advisable improvement in quality of life. (p. 24)

With regard to centre autonomy, schools should not operate without other social instances, but act as catalysts in the construction of community social networks that remove them from their traditional isolation. There are different models that back up the key importance of family and community participation in educational processes. Among the examples provided by [39] (pp. 46-50), we can pick out two:

a) School Development Programme (SDP): Developed by professor Comer, from the Child Study Center of Yale University, it emerged in response to the behavioural problems and poor performance of Afro-American pupils. The whole community needs to identify with pupils' education, following the African proverb: "it takes a whole village to raise a child" (sometimes it reads "it takes the whole tribe to educate a child"), since it considers as essential the commitment of all members of the educational community to achieve pupils' academic success and facilitate their psychological development. The programme includes a support team for teachers, and a team of relatives that strengthen community participation by volunteering in schools, becoming involved in the daily life of the school, giving support in classrooms, preparing reinforcement activities outside the school timetable, and the like.

b) Communities of Learning: This model is based on the dialogue and participation of the whole community to build and apply an educational programme that includes the communicative and instrumental dimensions of learning, and the promotion of positive expectations. It is also based on an accelerated conception of learning through measures that have proved successful in experiments (such as interactive groups, authorised libraries and training of relatives). It is equally imperative to include dialogue with the community, especially in terms of family participation. 
Learning is not only about school, but also about all kinds of resources - either school and family, municipal and community - available for pupils. Pupils' performance is influenced by and related to multiple circumstances and indicators, such as the socio-economic and cultural context, and families' status $[40,41]$. Therefore, in light of the studies mentioned above, if we want immigrant citizens' children to be able to succeed in school, it will be necessary to, in addition to school, implement mechanisms to strengthen social protection, to support families and to connect school education with out-of-school community education.

Indeed, some research on inclusive work with the immigrant population carried out at 31 educational centres in Andalusia [42], with the aim of understanding the situation in order to boost and improve the relationships between schools and communities in contexts of cultural diversity (among others), concluded that communicating with families about the programmes carried out at the centre decisively optimises the centre-family relationship, and that relying on families and involving them in activities at the centre helps to erase prejudices and stereotypes.

The relationship between the educational centre and pupils' families will incentivise the socialisation of pupils and families, for which it will be necessary to count on social mediators between educational centres and communities. According to some authors [43,44], today, as almost never before, schools find themselves at the crossroads of meeting the educational-training needs of pupils or of dealing with primary socialisation in a world that is becoming increasingly plural, heterogeneous and interconnected. It is evident that, whether at a crossroads or not, schools cannot dismiss both principles. However, it is also true that educational institutions seem unable to work without the indispensable support and contribution of families, given that they play an essential role in the integral education of minors due to the values that they transmit, the atmosphere they create, the affective relationships, etc., which have a strong impact by complementing or rejecting school work.

To this effect, a new term was coined to try to define the joint work between families and teachers: partnership. The overarching aim is to foster the bonds of union and cooperation between schools and families for the mutual benefit of both social institutions, and to increase pupils' educational quality through eight basic elements [45,46]: shared leadership, teamwork, action plans, the implementation of plans, financing, support from different contexts, assessment and permanent contact networks. Those centres that have operated from this perspective have registered better pupil performance, lower school absenteeism, better pupil behaviour at the centre and at home, and improved learning skills.

Furthermore, the educational community must fully understand the meanings and implications of the type of education to be implemented; and teachers, families and institutions must jointly prepare the school educational programme, as well as the processes and strategies to be activated to achieve those purposes $[10,11]$. In the analysis by [47] on families' participation in education centres, the author expressed that families prioritise what they perceive as "most profitable", what will have more direct and immediate repercussions for their children. It is important that families are convinced about the fact that teaching is a vital project for everyone, which requires everyone's commitment, including schools, but it is a mistake to think that this project ends with schools.

The connection, the collaborative work between the school and its environment is an indicator of the fostering of interculturalism, since this is a project that goes beyond the school walls, an interaction between the formal, the non-formal and the informal; hence, it is paramount to establish collaborative dynamics and joint actions among all the social and educational stakeholders [5]. In order to achieve such a goal, teachers must be trained in contextually framed intercultural education. Teachers themselves are asking for this, according to a study carried out by [48].

We cannot talk about building an intercultural society without considering democratic practice and citizen participation; to this regard, dialogue and collaboration between the school community and educational centres is imperative [28]. It is necessary to adopt an inclusive intercultural policy, to open education centres outside of traditional school hours, to reach agreements with cultural institutions, etc. Only this way will an intercultural society become reality [20]. As [49] argued, education is meaningful if it serves community development, because educational processes are conditioned by 
and are significant for economic, social, political and cultural structures in the context in which they develop. Every community has theoretical and practical knowledge of itself shared by its members thanks to dialogue and consensus [50,51]; and this knowledge makes it possible to establish processes of local improvement and development in the school community and its particular context. It is important to know how institutions are organised, given that the possibility of producing inclusive interactions relies on it [52].

Considering all of the above, the need to cultivate a public intelligence aimed at placing value on the public sphere as a cultural and political space for participation is compatible with [53] Schools haven forgotten minority cultures, what some authors [54,55] have called the funds of knowledge of minority cultural groups, traditional knowledge and skills historically accumulated and culturally developed by each social group, which are indispensable as the basis for building new knowledge. A community is created through individuals, and then the capacity of generating dynamic identities, since identity and otherness are linked concepts aligned with the creation of networks and, by extension, with communities of learning [56] that are but a group of projects for the improvement of schools and their environments. Education centres must foster community development projects [57] with the active involvement of educational agents [58], to promote local development that facilitates pupils' inclusion and increases the quality of the education system, the institutions and the organisations found in the intervention context; that is to say, open the school up to the outside.

Author Contributions: All authors contributed equally to this paper.

Funding: This research received no external funding.

Conflicts of Interest: The authors declare no conflict of interest.

\section{References}

1. Habermas, J. La constelación Postnacional. Ensayos Políticos; Paidós: Barcelona, Spain, 2000.

2. Escarbajal, A. Interculturalidad, Mediación y Trabajo Colaborativo; Narcea: Madrid, Spain, 2010.

3. Fiorin, I. Educazione interculturale alla cittadanza: Il ruolo della scuola. In L'educazione Interculturale alla Cittadinanza. La Scuola Come Laboratorio; Portera, A., Dusi, P., Guidetti, B., Eds.; Carocci: Roma, Spain, 2010; pp. 55-61.

4. Aznar, I.; Cáceres, M.P.; Hinojo, F.J. Formación integral: Educar para la convivencia y la paz. Rev. Iberoam. Educ. 2008, 46, 1-16.

5. Gómez, J. Convivencia, educación e interculturalidad. In Orientaciones para la Práctica de la Educación Intercultural; Ten, L.M., Tuts, M., Balaguer, X.L.I., Besalú, X., Lara, J.G., Sáez, F.T., Eds.; Wolters Kluwer: Madrid, Spain, 2012; pp. 125-136.

6. Arroyo, M.J. La educación intercultural: Un camino hacia la inclusión educativa. Incl. Educ. J. 2013, 6, 144-159.

7. Roldán, C.; y Cantillo, L. Formas alternativas a la resolución tradicional de conflictos: Las prácticas restaurativas. In Orientaciones Para la Práctica de la Educación Intercultural; Ten, L.M., Tuts, M., Balaguer, X.L.I., Besalú, X., Lara, J.G., Sáez, F.T., Eds.; Wolters Kluwer: Madrid, Spain, 2012; pp. 137-148.

8. Keast, J. Educazione interculturale e interreligiosa in Gran Bretagna. In Educazione Interculturale nel Contesto Internazionale; Portera, A., Ed.; Angelo Guerini: Milano, Italy, 2006; pp. 155-164.

9. Leiva, J.J. Interculturalidad, gestión de la convivencia y diversidad cultural en la escuela: Un estudio de las actitudes del profesorado. Revista Iberoamericana de Educación 2008, 46, 1-14.

10. Leiva, J.J. Las Esencias de la Educación Intercultural; Aljibe: Málaga, Spain, 2015.

11. Leiva, J.J. Interculturalidad y estilos de aprendizaje; nuevas perspectivas pedagógicas. Int. J. Educ. Res. Innov. 2015, 3, 36-51.

12. Zapata-Barrero, R. Del diálogo intercultural a la acción intercultural. In Manual para el Diseño de Políticas Interculturales; Zapata-Barrero y, R., Jiménez, G.P., Eds.; Universidad Pompeu Fabra: Barcelona, Spain, 2013; pp. 5-12.

13. Beach, D.; Dovemark, M. Making right choices: An ethnographic investigation on creativity and performativity in four Swedish schools. Oxf. Rev. Educ. 2009, 35, 689-704. [CrossRef] 
14. Marchesi, A. La inclusión educativa, una apuesta verdadera. Participación Educativa 2011, 18, 2-3.

15. Rodríguez, H. Marco de referencia internacional y modelos emergentes en educación inclusiva: Análisis sobre el enfoque inclusivo en educación. In Comunidades Interculturales y Democráticas; Frutos, E.A.E., Ed.; Narcea: Madrid, Spain, 2015; pp. 39-52.

16. Unión Europea. Tratado de Lisboa; Diario Oficial de la Unión Europea: Bruselas, Belgium, 2007; p. 306.

17. Sola, T. La escuela inclusiva: Una respuesta educativa para todos. En M. Lorenzo (Coord.). In Gestionando los Nuevos Actores y Escenarios de la Formación en la Sociedad del Conocimiento; Adhara: Granada, Spain, 2007; pp. 89-108.

18. Rogero, J. Escuela pública y derecho a la educación. Cuadernos de Pedagogía 2014, 443, 74-77.

19. Escudero, J.M. Avances y retos en la promoción de la innovación en los centros educativos. Educar. Edición Especial 30 Aniversario 2014, 50, 101-138.

20. García-Fernández, J.A. La dimensión intercultural en los documentos de planificación del centro escolar. In Orientaciones para la Práctica de la Educación Intercultural; Ten, L.M., Tuts, M., Balaguer, X.L.I., Besalú, X., Lara, J.G., Sáez, F.T., Eds.; Wolters Kluwer: Madrid, Spain, 2012; pp. 69-88.

21. Izquierdo, T.; Escarbajal, A.; y Latorre, P.A. Motivaciones que condicionan la formación y previenen la exclusión social de los futuros educadores. Revista de Investigación Educativa 2016, 34, 385-397. [CrossRef]

22. Giroux, H.A. Teoría y Resistencia en Educación; Siglo XXI: Madrid, Spain, 2004.

23. Giroux, H.A. Pedagogía y Política de la Esperanza; Amorrortu: Buenos Aires, Argentina, 2003.

24. Furman, G. Social justice leadership as praxis: Developing capacities through preparation programs. Quarterly 2012, 48, 191-229. [CrossRef]

25. García, J.A.; y Goenechea, C. Identificando buenas prácticas interculturales desde claves inclusivas. Revista Educación y Futuro Digital 2011, 5, 74-88. Available online: http://www.cesdonbosco.com/revista/ articulos2011/septiembre11/Mayka.pdf (accessed on 30 January 2019).

26. Gallego, B.; Rodríguez, H.; y Lago, M. Buenas prácticas en educación intercultural inclusiva. In Orientaciones para la Práctica de la Educación Intercultural; Ten, L.M., Tuts, M., Balaguer, X.L.I., Besalú, X., Lara, J.G., Sáez, F.T., Eds.; Tuts Wolters Kluwer: Madrid, Spain, 2012; pp. 53-68.

27. Santos Rego, M.A. Sostenibilidad y educación intercultural. El cambio de perspectiva. Bordón 2011, 63, $123-135$.

28. Cifuentes, L.M. Educación intercultural y democracia participativa en el ámbito comunitario. In Orientaciones para la Práctica de la Educación Intercultural; En, B., López y, M., Eds.; Tuts Wolters Kluwer: Madrid, Spain, 2012.

29. Revilla, A.; y Olivares, P. La interculturalidad desde la Educación Artística. Las posibilidades curriculares a través del Arte Negroafricano. DEDICA. Revista de Educación y Humanidades 2019, 15, 173-184. [CrossRef]

30. Catarsi, M. Per una scuola aperta a tutti. Immigrazione e educazione interculturale. In Strumenti di Recerca per l'innovazione e la Qualitá in Ambito Educativo; Universitá degli Studi: Roma, Italy, 2010; pp. 111-120.

31. Ballesteros, B.; Aguado, M.T.; y Málik, B. Escuelas para todos: Diversidad y educación obligatoria. Rev. Electrónica Interuniv. Form. Profr. (REIFOP) 2014, 17, 93-107. [CrossRef]

32. Bailo, F.M.; y Pinos, M. La interculturalidad como respuesta. In Informe anual sobre el racismo en el Estado español; En SOS Racismo, Ed.; Federación de Asociaciones de SOS Racismo: Madrid, Spain, 2015; pp. 111-119.

33. Aguado, M.T.; Ballesteros, B. Investigando la escuela intercultural. Experiencias y resultados del grupo INTER. In Comunidades Interculturales Y Democráticas; Frutos, A.E., Ed.; Narcea Ediciones: Madrid, Spain, 2015; pp. 99-112.

34. Essomba, M.A. Políticas de escolarización del alumnado de origen extranjero en el Estado español hoy. Análisis y propuestas. Revista Electrónica Interuniversitaria de Formación del Profesorado (REIFOP) 2014, 17, $13-27$.

35. Ministerio de Educación; Cultura y Deportes. Datos y cifras. Curso Escolar 2014-2015; Secretaría General Técnica. Subdirección General de Documentación y Publicaciones: Madrid, Spain, 2014.

36. Sánchez, A.; y Sandín, M.P. Joves inmigrants i persistencia acadèmica: Què ens diuen les seues xarxes personals. Temps d'Educació 2013, 44, 177-190.

37. Mourshed, M.; Chijioke, C.; Barber, M. How the Word'S Most Improved School System Keep Getting Better; Mckinsey Report: London, UK, 2011.

38. Delors, J. La Educación Encierra un Tesoro; Santillana-Ediciones UNESCO: Madrid, Spain, 1996; pp. $43-51$.

39. Rodríguez García, J.A. La integración intercultural en España: El mestizaje constitucional democrático. Migraciones Internacionales 2011, 6, 193-222. 
40. European Commission Education and Migration. Strategies for Integrating Migrant Children in European Schools and Societies; European Commission: Bruselas, Belgium, 2008.

41. Instituto de Evaluación. PISA 2009. Programa para la Evaluación Internacional de los Alumnos. Informe Español; Ministerio de Educación: Madrid, Spain, 2009.

42. Márquez, E.; y García-Cano, M. Educación Intercultural Y Comunidades de Aprendizaje; Los Libros de la Catarata: Madrid, Spain, 2012.

43. Karousiou, K.; Hajisoteriou, C.; y Angelides, P. Teachers' professional identity in super-diverse school settings: Teachers as agents of intercultural education. Teach. Teach. Educ. 2019, 25, 240-258. [CrossRef]

44. Martínez Ferrer, B.; Musitu, G.; y Amador, L.V. La relación entre familia y escuela. Un recurso ante la globalización. In Exclusión Social y Diversidad; En, L., y Amador, V., Musitu, G., Eds.; Trillas: México City, México, 2011; pp. 221-242.

45. Epstein, J.L. School and family partnerships. In Encyclopaedia of Educational Research; Alkin, E.M., Ed.; MacMillan: New York, NY, USA, 2011; pp. 1139-1151.

46. García-Bacete, F.J.; y Martínez González, R.A. La relación entre los centros escolares, las familias y los entornos comunitarios como factor de calidad de la educación de menores y adultos. Cultura y Educación 2006, 18, 213-218. [CrossRef]

47. Garreta, J. La participación de las familias en la escuela. In Sociología de la educación secundaria; Feito, E.R., Ed.; Graó: Barcelona, Spain, 2010; pp. 45-70.

48. Cernadas, F.; Santos Rego, M.A.; y Lorenzo, M. Los profesores ante la educación intercultural: El desafío de la formación sobre el terreno. Revista de Investigación Educativa 2013, 31, 555-570. [CrossRef]

49. Gutiérrez, F. Educación de adultos y comunicación social. In Siete Visiones de la Educación de Adultos; CREFAL: Patzcuato, 1984; pp. 33-43.

50. López, J.; Sánchez, M.; y Altopiedi, M. Comunidades profesionales de práctica que logran sostener procesos de mejora institucional en las escuelas. Revista de Educación 2011, 356, 109-131.

51. Valiandes, S.; Neophytou, L.; y Hajisoteriou, C. Establishing a framework for blending intercultural education with differentiated instruction. Intercult. Educ. 2018, 29, 379-398. [CrossRef]

52. Besalú, X. Interculturalidad: La resocialización del profesorado. In Orientaciones para la Práctica de la Educación Intercultural; España, W.K., Ed.; Wolters Kluwer: Madrid, Spain, 2012; pp. 109-123.

53. Escudero, J.M. Comunidades docentes de aprendizaje, formación del profesorado y mejora de la educación. Ágora para la EF y el Deporte 2009, 10, 7-31.

54. González, N.; Moll, L.; y Amanti, C. Funds of Knowledge. Theorizing Practiques in Households, Communities, and Classrooms; Lawrence Erlbaum: Mahwah, NJ, YSA, 2005.

55. Rodríguez, G.M. Power and agency in education: Exploring the pedagogical dimensions of funds of knowledge. Rev. Res. Educ. 2013, 37, 87-120. [CrossRef]

56. Augé, M. La Comunidad Ilusoria; Gedisa: Barcelona, Spain, 2012.

57. Essomba, M.A. 10 ideas clave. La gestión de la Diversidad Cultural en la Escuela; Graó: Barcelona, Spain, 2008.

58. Hajisoteriou, C.; Karousiou, C.; y Angelides, P. INTERACT: Building a virtual community of practice to enhance teachers' intercultural professional development. Educ. Media Int. 2018, 55, 15-33. [CrossRef]

(C) 2019 by the authors. Licensee MDPI, Basel, Switzerland. This article is an open access article distributed under the terms and conditions of the Creative Commons Attribution (CC BY) license (http://creativecommons.org/licenses/by/4.0/). 